\title{
Water-use dynamics of an alien-invaded riparian forest within the Mediterranean climate zone of the Western Cape, South Africa
}

\author{
Bruce C. Scott-Shaw ${ }^{1}$, Colin S. Everson ${ }^{1,2,3}$, and Alistair D. Clulow ${ }^{1}$ \\ ${ }^{1}$ Center for Water Resources Research, School of Agriculture, Earth and Environmental Sciences, \\ University of KwaZulu-Natal, Private Bag X01, Scottsville, Pietermaritzburg 3209, South Africa \\ ${ }^{2}$ South African Environmental Observation Network (SAEON), Grasslands-Wetlands-Forests Node, \\ 1 Peter Brown Drive, Queen Elizabeth Park, Montrose, Pietermaritzburg 3201, South Africa \\ ${ }^{3}$ Department of Plant and Soil Sciences, University of Pretoria, Private Bag X20, Hatfield, Pretoria 0028, South Africa \\ Correspondence to: Bruce C. Scott-Shaw (brucecharlesss@gmail.com)
}

Received: 9 December 2016 - Discussion started: 16 January 2017

Revised: 9 May 2017 - Accepted: 13 May 2017 - Published: 13 September 2017

\begin{abstract}
In South Africa, the invasion of riparian forests by alien trees has the potential to affect the country's limited water resources. Tree water-use measurements have therefore become an important component of recent hydrological studies. It is difficult for South African government initiatives, such as the Working for Water (WfW) alien clearing program, to justify alien tree removal and implement rehabilitation unless hydrological benefits are known. Consequently, water use within a riparian forest along the Buffeljags River in the Western Cape of South Africa was monitored over a 3-year period. The site consisted of an indigenous stand of Western Cape afrotemperate forest adjacent to a large stand of introduced Acacia mearnsii. The heat ratio method of the heat pulse velocity sap flow technique was used to measure the sap flow of a selection of indigenous species in the indigenous stand, a selection of $A$. mearnsii trees in the alien stand and two clusters of indigenous species within the alien stand. The indigenous trees in the alien stand at Buffeljags River showed significant intraspecific differences in the daily sap flow rates varying from 15 to $32 \mathrm{~L} \mathrm{day}^{-1}$ in summer (sap flow being directly proportional to tree size). In winter (June), this was reduced to only $7 \mathrm{~L} \mathrm{day}^{-1}$ when limited energy was available to drive the transpiration process. The water use in the A. mearnsii trees showed peaks in transpiration during the months of March 2012, September 2012 and February 2013. These periods had high average temperatures, rainfall and high daily vapor pressure deficits (VPDs - average of $1.26 \mathrm{kPa}$ ). The average daily sap flow ranged from 25 to $35 \mathrm{~L}$ in summer and approximately $10 \mathrm{~L}$ in the winter. The com-
\end{abstract}

bined accumulated daily sap flow per year for the three Vepris lanceolata and three A. mearnsii trees was 5700 and $9200 \mathrm{~L}$, respectively, clearly demonstrating the higher water use of the introduced Acacia trees during the winter months. After spatially upscaling the findings, it was concluded that, annually, the alien stand used nearly 6 times more water per unit area than the indigenous stand $\left(585 \mathrm{~mm} \mathrm{a}^{-1}\right.$ compared to $101 \mathrm{~mm} \mathrm{a}^{-1}$ ). This finding indicates that there would be a gain in groundwater recharge and/or streamflow if the alien species are removed from riparian forests and rehabilitated back to their natural state.

\section{Introduction}

While extensive research has been undertaken on the water use of terrestrial ecosystems in South Africa, little is known about the water use and growth of trees growing in riparian areas. This knowledge gap, as well as the poor ecological conditions of South African riparian habitats, has led to uncertainty and contention over riparian rehabilitation techniques. The deep fertile soils, with high soil moisture contents associated with riparian areas, make them ideal for plant establishment and growth (Everson et al., 2007). As such, these areas are extremely vulnerable to invasion by pioneer plant species, particularly alien species that have historically been introduced for commercial forestry. Riparian zone vegetation, which can be described as the interface between terrestrial and aquatic ecosystems (Richardson et al., 2005), has 
a significant impact on the hydrology of a catchment due to the close proximity of riparian vegetation rooting systems to the water table. Most riparian trees are phreatophytic, meaning they have access to a permanent source of water because their rooting system is within the shallow groundwater.

Through the process of evaporation and transpiration, riparian vegetation influences streamflow rates, groundwater levels and local climates (Richardson et al., 2005). Vegetation along riverbanks filter surface and subsurface water moving laterally through the soil towards the river channel. This helps to maintain channel water quality, by regulating the water temperature (through shading), bank stability and turbidity (through root colonization and surface cover), and traps debris (Askey-Dorin et al., 1999). Riparian vegetation can access a wide range of water sources within the riparian zone, which includes rainfall, soil water, stream water and groundwater (O'Grady et al., 2006). Commercial forestry has been blamed for increasing the green water (water lost by total evaporation) and decreasing the blue water (water in rivers and dams) in areas across South Africa (Jewitt, 2006). Introduced tree species change the natural landscape by altering the stream banks and thereby increasing soil erosion, altering fire regimes, as well as changing the physical and chemical composition of the soil (Joshi et al., 2004; Le Maitre et al., 1996; Tabacchi et al., 2000). For these reasons, invasive alien plants, particularly introduced commercial trees, are considered to be a major threat to biodiversity globally (Reid et al., 2009; Solarz, 2007; Wal et al., 2008). There is a widespread belief in South Africa and globally that indigenous tree species, in contrast to the introduced trees, are water efficient and should be planted more widely in land restoration programs. This is based on observations that indigenous trees are generally slow growing and that growth and water use are broadly linked (Everson et al., 2007; Gush, 2011). However, tree water use is technically difficult and expensive to measure, and so there is scant evidence of low water use by indigenous trees in South Africa. A global review of water-use differences between introduced invasive and indigenous (native) plants at the leaf, plant and ecosystem scales (Cavaleri and Sack, 2010) indicates that invasive plants use up to $136 \%$ more water than the indigenous species at the leaf scale (Baruch and Fernandez, 1993; Dixon et al., 2004; Pratt and Black, 2006). At the plant scale, there is a diverse range in water use ranging from the invasive species using comparatively $100 \%$ less to $150-300 \%$ more water than the indigenous species (Cleverly et al., 1997; Nagler et al., 2003; Kagawa et al., 2009). At the ecosystem scale, studies indicate that invasive species use $189 \%$ more water than indigenous-dominated stands, particularly in tropical moist forests (Nosetto et al., 2005; Yepez et al., 2005; Fritzsche et al., 2006). In the high rainfall areas of South Africa, invasive alien plants growing in riparian areas are estimated to reduce annual streamflow by $523 \times 10^{6} \mathrm{~m}^{3}$ with a predicted annual reduction estimated to be as high as $1314 \times 10^{6} \mathrm{~m}^{3}$ if allowed to reach a fully invaded state (Cullis et al., 2007).
Management of invaded riparian zones can result in hydrological gains disproportionately greater than the catchment area affected, with up to 3 times more streamflow yield than upslope areas (Scott and Lesch, 1996; Scott, 1999).

For many field and modeling applications, accurate estimates of total evaporation (ET) are required but are often lacking. Modeled estimates are often used without proper validation, and the verification of the results is questionable, especially in dynamic and highly sensitive riparian areas. With the ongoing development of micrometeorological techniques, it is possible to accurately quantify the various components of the water cycle over various terrestrial surfaces. The use of micrometeorological techniques is largely dependent on location, time constraints and available funds. However, due to continuous research, the implementation of these techniques has become faster and more easily understood. In addition, comparisons between techniques and upscaling have become possible, allowing for greater freedom in the choice of techniques and the length of measurement (Savage et al., 2004; Jarmain et al., 2008). Sap flux density measurements give precise information on flow directions as well as spatial and temporal flow distribution (Vandegehuchte and Steppe, 2013). The heat pulse velocity (HPV) method is the most accurate of the available methods when compared against gravimetric methods (Steppe et al., 2010; Vandegehuchte and Steppe, 2013).

The Buffeljags River site in the Western Cape has been an ecological research site since 2006 (Geldenhuys, ongoing) and forms part of a selective thinning experiment designed to assist Working for Water (WfW) clearing programs. The government-funded WfW program clears catchment areas of invasive alien plants with the aim of restoring hydrological functioning while also providing poverty relief to local communities through job creation (Turpie et al., 2008). The aim of this study was to measure tree water use to quantify the potential hydrological benefit of these forest management practices.

\subsection{The study area}

The Buffeljags River flows southwards along the Langeberg west mountain range into the Buffeljags Dam. The Buffeljags River study area is at latitude $34^{\circ} 00^{\prime} 15^{\prime \prime} \mathrm{S}$ and longitude $20^{\circ} 33^{\prime} 58^{\prime \prime} \mathrm{E}$ (Fig. 1), approximately $95-110 \mathrm{~m}$ above mean sea level. The research area is within the Western Cape afrotemperate forest type which is characterized by very small forest patches occurring along boulder screes consisting of streams, gorges and mountain slopes (Geldenhuys, 2010). The surrounding vegetation type is south Langeberg sandstone fynbos (Mucina and Rutherford, 2011). The Langeberg Mountains consist of Table Mountain sandstone/quartzite (north of the Buffeljags River) with a ridge of shales to the south of the river. The soils are characterized by structureless sands, a result of previous alluvial deposition. The climate is typical of the Western Cape with 


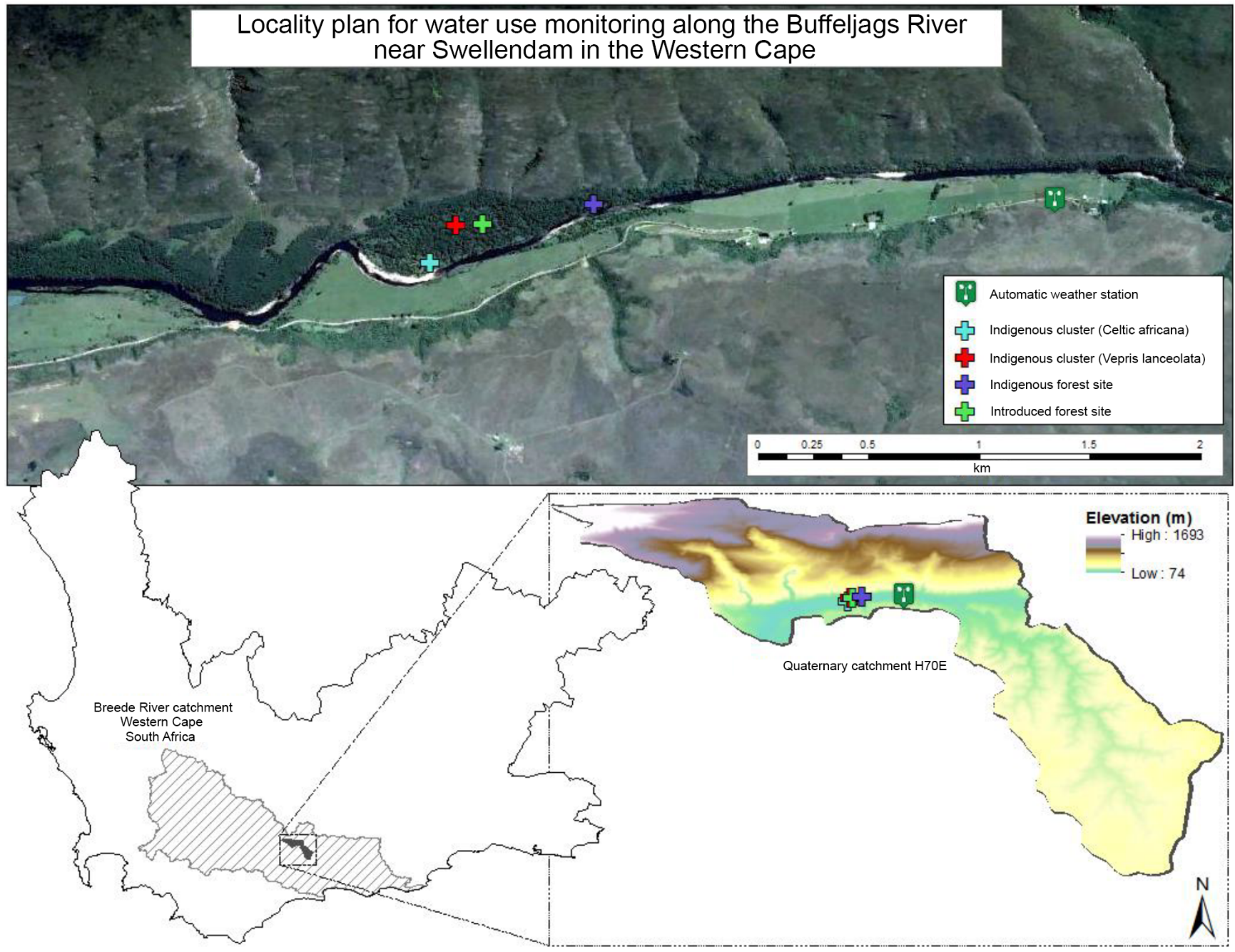

Figure 1. Location of the Buffeljags River research area within the Western Cape, South Africa.

hot summers and cold winters. However, the rainfall is fairly evenly spread throughout the year. The long-term (137-year record) mean annual precipitation (MAP) at Buffeljags River is $636 \mathrm{~mm} \mathrm{a}^{-1}$. The daily maximum temperatures range from $17.1^{\circ} \mathrm{C}$ in July to $27.5^{\circ} \mathrm{C}$ in January. The mean daily minimum temperature is $15^{\circ} \mathrm{C}$ in February and $5^{\circ} \mathrm{C}$ in July. A 99 ha riparian forest occurs along the river with 75 ha of invaded forest (lower reach) and 24 ha of pristine indigenous forest (upper reach) (Fig. 1), comprising of species such as Celtis africana, V. lanceolata, Prunus africana, Rapanea melanophloeos and Afrocarpus (Podocarpus falcatus). The stand height ranges from 3 to $15 \mathrm{~m}$ in the indigenous stand and 11 to $17 \mathrm{~m}$ in the alien stand. The surrounding vegetation is mountainous fynbos and renosterveld.

Historically, A. mearnsii trees were planted for firewood and building material on the nearby farms. Working for Water cleared most of the alien trees which have since grown back over the last 15 years. Currently, the invasion extends approximately $1 \mathrm{~km}$ along the river.

\subsection{The study sites}

Three representative trees within the indigenous stand were instrumented for monitoring sap flow. These trees included an understory tree (Rothmania capensis), one medium ( $V$. lanceolata) and one large evergreen tree ( $V$. lanceolata) that were most common throughout the stand. The leaf area index (LAI) within this stand was 3.6 throughout most of the year with a slight reduction during the winter months. Downstream of this site, within the alien stand (Fig. 1), three $A$. mearnsii trees were instrumented over the 3-year study period. In a similar way, small, medium and large diameter classes were chosen to assist in the upscaling of single-tree transpiration measurements of the A. mearnsii trees. The LAI of the A. mearnsii stand was 3.1 during the summer months and 2.8 during the winter months. Two indigenous tree clusters within the alien stand were also instrumented. The $V$. lanceolata cluster contained two medium and one large diameter class trees (LAI of 3.4) while the $C$. africana clus- 
Table 1. Tree physiology and specific data required for the calculation of sap flow and upscaling.

\begin{tabular}{lrlrrrr}
\hline $\begin{array}{l}\text { Indigenous forest } \\
\text { site (upper reach) }\end{array}$ & $\begin{array}{r}\text { Diameter } \\
(\mathrm{mm})\end{array}$ & $\begin{array}{l}\text { Size } \\
\text { class* }\end{array}$ & $\begin{array}{r}\text { Moisture } \\
\text { fraction }\end{array}$ & $\begin{array}{r}\text { Average wounding } \\
(\mathrm{mm})\end{array}$ & $\begin{array}{r}\text { Wood density } \\
\left(\mathrm{m}^{3} \mathrm{~kg}^{-1}\right)\end{array}$ & $\begin{array}{r}\text { Representative stem } \\
\text { density }(\text { stems ha }\end{array}$ \\
\hline Rothmania capensis & 125 & Small & 0.45 & 2.8 & 0.59 & 120 \\
V. lanceolata & 134 & Medium & 0.42 & 3.7 & 0.63 & 65 \\
V. lanceolata & 199 & Large & 0.42 & 3.4 & 0.66 & 24 \\
\hline
\end{tabular}

\begin{tabular}{|c|c|c|c|c|c|c|}
\hline \multicolumn{7}{|c|}{$\begin{array}{l}\text { Introduced/alien forest } \\
\text { site (lower reach) }\end{array}$} \\
\hline Acacia mearnsii & 121 & Small & 0.89 & 3.2 & 0.54 & 650 \\
\hline Acacia mearnsii & 167 & Medium & 0.47 & 3.2 & 0.73 & 200 \\
\hline Acacia mearnsii & 194 & Large & 0.71 & 3.0 & 0.61 & 50 \\
\hline \multicolumn{7}{|l|}{$\begin{array}{l}\text { Indigenous cluster } \\
\text { (lower reach) }\end{array}$} \\
\hline V. lanceolata & 166 & Medium & 0.45 & 3.2 & 0.66 & 65 \\
\hline V. lanceolata & 174 & Medium & 0.45 & 3.2 & 0.65 & 65 \\
\hline V. lanceolata & 202 & Large & 0.47 & 2.9 & 0.66 & 24 \\
\hline \multicolumn{7}{|l|}{$\begin{array}{l}\text { Indigenous cluster } \\
\text { (lower reach) }\end{array}$} \\
\hline C. africana & 319 & Large & 0.52 & 6.1 & 0.71 & 24 \\
\hline C. africana & 422 & Large & 0.50 & 6.0 & 0.71 & 24 \\
\hline
\end{tabular}

* Note that the stem density was grouped as per size class.

ter contained two large diameter class trees with a LAI of 3.3 in the summer months and 1.8 during the winter months. The LAI provided an indication of the seasonal physiological changes of the trees and the light variations between the sites.

Both the indigenous and introduced alien stands were in a climax state with most of the canopy trees falling into the medium or large size classes. Although there were many smaller trees (excluding trees with a $\varnothing<5 \mathrm{~mm}$ ), these did not contribute significantly to the total transpiration as they were shaded out by the climax trees. An overview of the individual tree characteristics has been provided in Table 1. Variations in stem moisture content were possibly due to the different ages and sizes of the trees measured (variations in sap wood depth and active xylem concentration).

\section{Methods}

A meteorological station was established on 25 January 2012 at Buffeljags River in a nearby planted Eragrotis plana field, $1.6 \mathrm{~km}$ from the indigenous site. Rainfall (TE525, Texas Electronics Inc., Dallas, Texas, USA) was measured at a height of $1.2 \mathrm{~m}$ from the ground, with additional measurements at a height of $2 \mathrm{~m}$ for air temperature and relative humidity (HMP45C, Vaisala Inc., Helsinki, Finland), solar irradiance (LI-200, LI-COR, Lincoln, Nebraska, USA), net radiation (NR-Lite, Kipp and Zonen, Delft, the Netherlands), and wind speed and direction (model 03002, R. M. Young, Tra- verse city, Michigan, USA). These were measured at a $10 \mathrm{~s}$ interval and the appropriate statistical outputs were recorded every hour.

A HPV system using the heat ratio algorithm (Burgess et al., 2001) was set up to monitor long-term sap flow on all of the selected trees over a 3 -year period. The instrumentation is described by Clulow et al. (2013) and included a $0.5 \mathrm{~s}$ heat source (sap flow trace) in the form of a line heater. A pair of type-T thermocouple probes was used to measure preand post-temperatures $5 \mathrm{~mm}$ above (downstream) and below (upstream) of the heater probe (Clulow et al., 2013). Hourly measurements (CR1000, Campbell Scientific Inc., Logan, Utah, USA) were captured over the 3-year monitoring period (January 2012 to March 2015). Monthly checks were undertaken to adjust probe depths in order to account for radial stem growth if required.

An assessment of the bark and sapwood depth was undertaken on the selected trees using an increment borer. This assessment assisted in determining the HPV probe insertion depths and the calculation of sapwood area. The heat pulse velocity $\left(V_{\mathrm{h}}-\mathrm{cm} \mathrm{h}^{-1}\right)$ was calculated from

$V_{\mathrm{h}}=\frac{k}{x} \ln \left(\frac{V_{1}}{V_{2}}\right) 3600$,

where $k$ is the thermal diffusivity of green (fresh) wood, $x$ is the distance $(5 \mathrm{~mm})$ above and below the heater (representing upstream and downstream), and $v_{1}$ and $v_{2}\left({ }^{\circ} \mathrm{C}\right)$ are increases in the downstream and upstream temperatures 
(from initial average temperatures), respectively. A thermal diffusivity ( $k$ ) of $2.5 \times 10^{-3} \mathrm{~cm}^{2} \mathrm{~s}^{-1}$ (Marshall, 1958) was used. Wounding or damaged xylem (non-functional) around the thermocouples were accounted for using wound correction coefficients described by Swanson and Whitfield (1981). Sap velocities were then calculated by accounting for wood density and sapwood moisture content as described by Marshal (1958). Finally, sap velocities were converted to tree water use $\left(Q_{\text {tree }}\right)$ or sap flow $\left(\mathrm{L} \mathrm{h}^{-1}\right)$ by calculating the sum of the products of sap velocity and cross-sectional area for individual symmetrical tree stems (Clulow et al., 2013).

Tree growth was recorded every 2 months throughout the monitoring period by measuring diameter at breast height with a dendrometer, and canopy height was recorded using a VL402 hypsometer (Haglöf, Sweden). Leaf area index (LAI-2200, LI-COR, Lincoln, Nebraska, USA) was measured monthly under each stand. Riparian forests typically have a narrow canopy with limited aerodynamic fetch, which excludes techniques such as eddy covariance and scintillometry being used to support the upscaling of point water-use measurements to stand water-use values. Due to the homogenous composition of the alien stand and the dominance of $V$. lanceolata and C. africana species within the indigenous stand, a methodology was followed based on recent upscaling studies (Ford et al., 2004; Miller et al., 2007). In addition, detailed stem density data were available for the site due to extensive ongoing ecological research (Atsame-Edda, 2014). Medoid (representative of the population) trees were selected for sap flow measurement. This included the most commonly occurring alien and indigenous species (canopy and understorey) and a range of size classes for each species. A species density analysis was undertaken $(\varnothing>50 \mathrm{~mm})$ in replicated $400 \mathrm{~m}^{2}$ plots per site. A relationship between total tree water use $\left(Q_{\text {tree }}-\mathrm{Lday}^{-1}\right)$ and each representative size and species class was identified. This allowed for the estimation of the stand water flux ( $\left.Q_{\text {stand }}\right)$ which was divided by the plot area $\left(400 \mathrm{~m}^{2}\right)$ in order to obtain comparative units between the indigenous and alien stands $\left(\mathrm{Lday}^{-1} \mathrm{ha}^{-1}\right)$. These values were then accumulated to annual values so that the effect of alien and indigenous (evergreen and deciduous) stands on the water balance could be quantified throughout a hydrological year.

The A. mearnsii site had a thin litter layer consisting mostly of broken branches, bark and leaves compared with the indigenous site which had a thicker litter layer with a large amount of organic matter accumulated from the various tree species and understorey vegetation. Volumetric soil water contents were measured hourly at both the indigenous and alien sites (concurrent to the HPV measurements) with three time domain reflectometry (TDR) probes (Campbell Scientific CS 615) installed horizontally at each site at depths of $0.1,0.3$ and $0.5 \mathrm{~m}$. The TDR probes were connected to spare channels on the CR1000 data logger of the HPV system. With hourly volumetric water content measurements, the response of trees to rainfall events or stressed conditions was monitored and supported the interpretation of the HPV measurements. An observation borehole was installed at the site to monitor the groundwater recharge as well as to confirm the assumption that all the trees within the riparian forest had direct access to groundwater. Soil samples were taken to determine the distribution of roots, bulk density and soil water content. These samples (taken at various depths throughout the profile) were weighed before and after oven drying to determine the soil characteristics.

\section{Results}

\subsection{Weather conditions during the study period}

The mean annual precipitation (MAP) over the 3-year study was significantly higher than the long-term average $\left(636 \mathrm{~mm} \mathrm{a}^{-1}\right.$ ) by $300-500 \mathrm{~mm} \mathrm{a}^{-1}$ (2012 to 2014 being 1017, 902 and $1127 \mathrm{~mm} \mathrm{a}^{-1}$, respectively). The rainfall distribution was variable (lacking a seasonal trend) throughout the 3 years with a mean monthly value of $85 \mathrm{~mm} \mathrm{a}^{-1}$ (Fig. 2). There were numerous days of high hourly rainfall (to a maximum of $30 \mathrm{~mm} \mathrm{~h}^{-1}$ and $102 \mathrm{~mm} \mathrm{day}^{-1}$ ) demonstrating the prevalence of high-intensity storms at the site (Fig. 3). The solar radiation peaked at $34 \mathrm{MJ} \mathrm{m}^{-2}$ day $^{-1}$ following the same seasonal trend to that of the daily minimum and maximum temperatures.

The relative humidity $(\mathrm{RH})$ ranged from 20 to $90 \%$, with little seasonal trend. During periods of high solar radiation, the vapor pressure deficit was high and correlated to peaks in transpiration rates. An average daily temperature of $22.1{ }^{\circ} \mathrm{C}$ was recorded at Buffeljags River in the summer months. During these months, daily maximum temperatures occasionally exceeded $40^{\circ} \mathrm{C}$. During the winter months, the temperatures averaged $12.1^{\circ} \mathrm{C}$ due to numerous days with low solar radiation, such as during rainfall events and cloudy days, and would likely result in little to no transpiration occurring. The daily reference total evaporation $\left(\mathrm{ET}_{\mathrm{o}}\right)$, derived from data captured at the meteorological station, averaged approximately $1 \mathrm{~mm} \mathrm{day}^{-1}$ in the winter period to $4 \mathrm{~mm} \mathrm{day}^{-1}$ during the summer period. The daily $\mathrm{ET}_{\mathrm{o}}$ peaked at $7.5 \mathrm{~mm} \mathrm{day}^{-1}$, which correlated to peaks in measured transpiration.

\subsection{Tree water use}

For comparative purposes, the water use of similar-sized $V$. lanceolata and A. mearnsii trees were compared during the wet and the dry seasons (Figs. 4 and 5). During the summer month of January, the $V$. lanceolata tree water use exhibited seasonal curves indicative of the clear sunny days and high correlation to the solar radiation. The medium-sized $V$. lanceolata $(\varnothing 17.4 \mathrm{~cm})$ used an average of $24 \mathrm{~L} \mathrm{day}^{-1}$ during the summer months (October-March) and an average of $8 \mathrm{~L} \mathrm{day}^{-1}$ during the winter months (April-September) (Fig. 4). The medium-sized A. mearnsii $(\varnothing 16.7 \mathrm{~cm})$ used an 


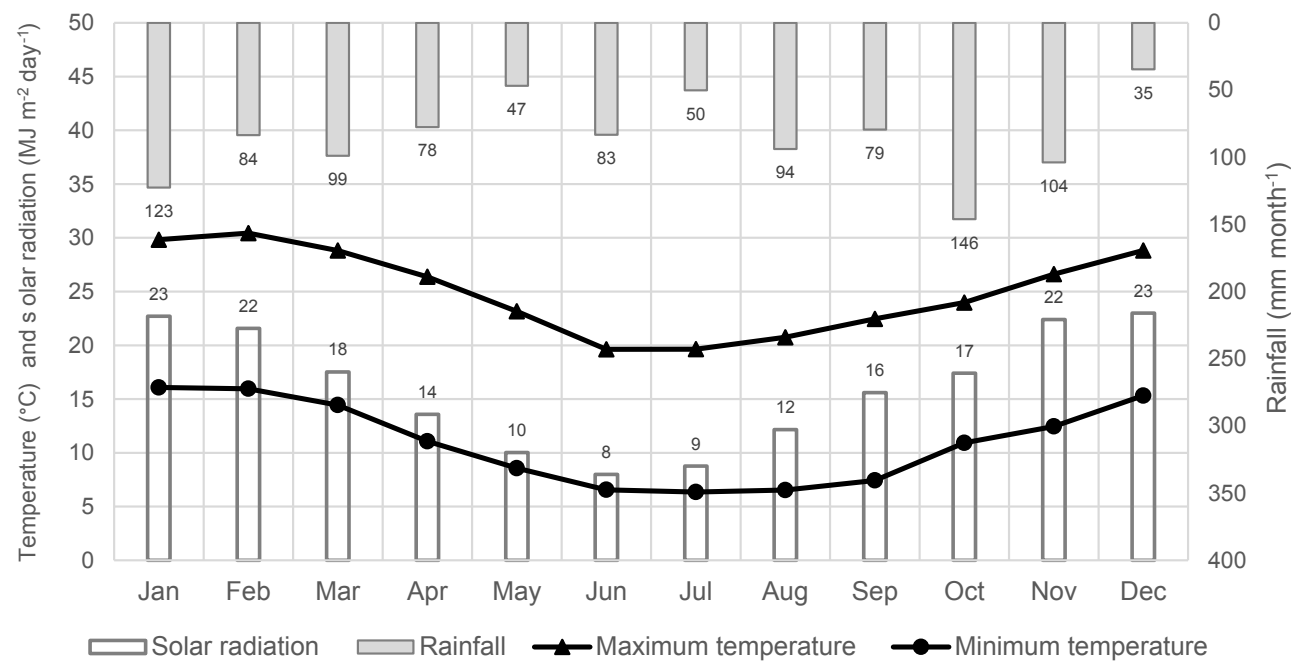

Figure 2. The monthly rainfall, monthly solar radiant density, and average monthly maximum and minimum air temperatures at Buffeljags River averaged over 3 years.

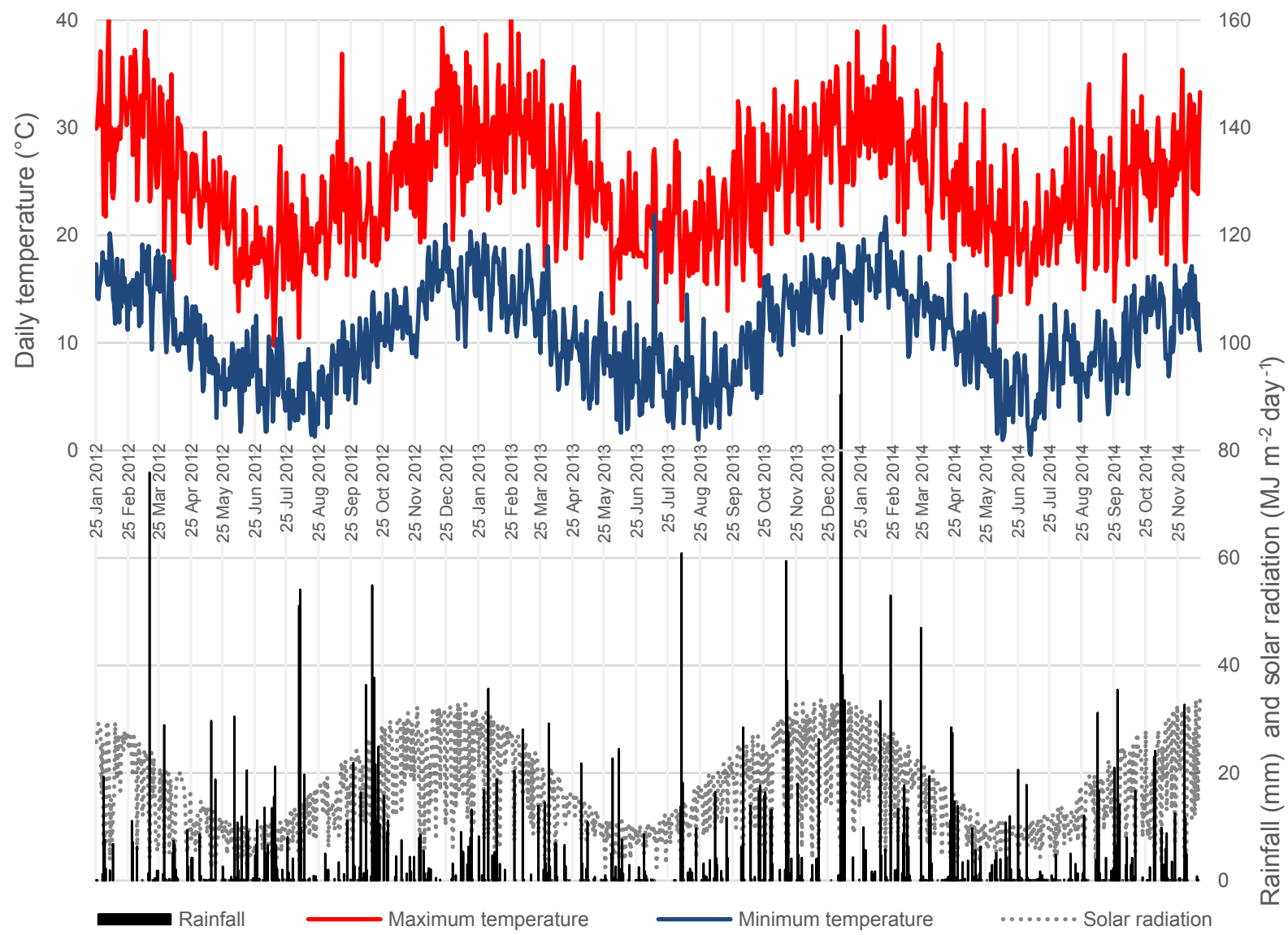

Figure 3. The daily rainfall, solar radiation and maximum and minimum air temperatures at Buffeljags River.

average of $10 \mathrm{~L} \mathrm{day}^{-1}$ in the winter months, similar to that of the $V$. lanceolata. In the summer months, the A. mearnsii used an average of $39 \mathrm{~L} \mathrm{day}^{-1}$, significantly higher than the indigenous tree (Fig. 5). During significant rainfall periods
( $>5 \mathrm{~mm}$ ), there was little to no water use in both trees due to the low evaporative demand and the wet canopy.

Individual whole-tree water use was significantly reduced in winter (May and June) for most of the trees, dropping by 


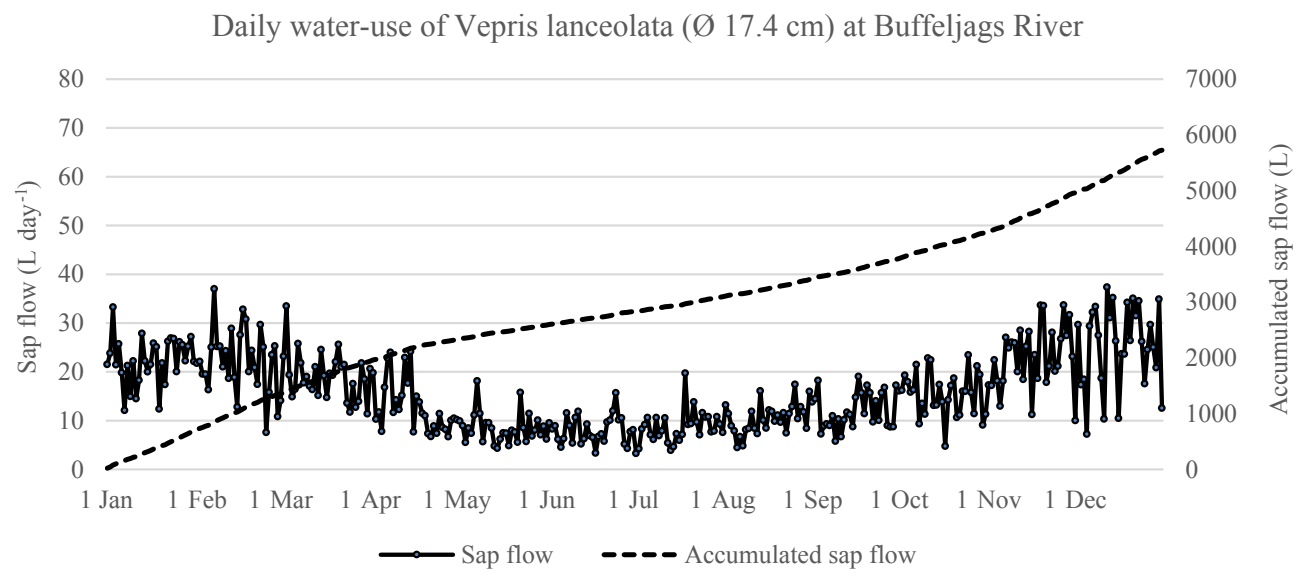

Figure 4. Sap flow (daily and accumulated) from an indigenous V. lanceolata in the lower-reach stand at Buffeljags River (January 2012 to March 2015) averaged over 3 years.

Daily water-use of Acacia mearnsii (Ø $16.7 \mathrm{~cm})$ at Buffeljags River

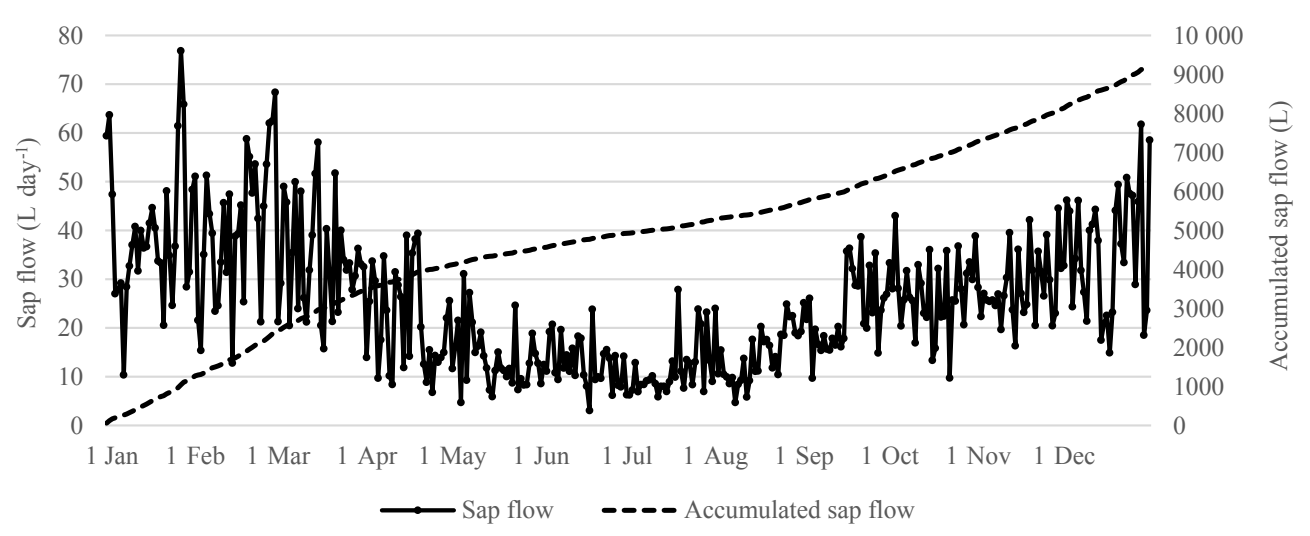

Figure 5. Sap flow (daily and accumulated) from an alien-invasive Acacia mearnsii in the lower-reach stand at Buffeljags River (January 2012 to March 2015) averaged over 3 years.

approximately $75 \%$ from the peak water use. This was attributed to fewer daylight hours in the winter months which resulted in reduced available energy at this time of year to drive the transpiration process. From November 2012 to March 2013, all species showed a significant increase in water use during this hot summer period. The water use in the A. mearnsii trees showed a distinct peak in transpiration during the months of March 2012, September 2012 and February 2013. During March 2012, the high average temperature $\left(21.5^{\circ} \mathrm{C}\right), \mathrm{a} 76 \mathrm{~mm} \mathrm{day}^{-1}$ rainfall event and high daily vapor pressure deficits (VPDs) (average of $1.26 \mathrm{kPa}$ ) contributed to a high atmospheric demand. On cloudless days with a high VPD and high soil water content, the trees would be expected to use more water than during overcast days. The average daily sap flow ranged from $15 \mathrm{Lday}^{-1}$ in the smaller-class tree, $25 \mathrm{~L} \mathrm{day}^{-1}$ in the medium-class tree and $39 \mathrm{Lday}^{-1}$ in the large-class tree (Tables 1 and 2).

The daily summer water use of two of the $V$. lanceolata trees (Table 2) in the upper indigenous stand showed high water use with an average of $19 \mathrm{~L} \mathrm{day}^{-1}$ (medium class) and $37 \mathrm{~L} \mathrm{day}^{-1}$ (large class). The high water use in the large tree was ascribed to its size and deep rooting system which is presumed to have had easy access to groundwater at this site due to the proximity to the river ( $10 \mathrm{~m}$ horizontal distance). This was verified with the borehole levels and a root analysis at the site. The water level ranged from 3.2 to $4.8 \mathrm{~m}$ below ground level at the site where roots were observed to $5 \mathrm{~m}$. The water use of the small understorey tree $R$. capensis had a much lower water use (average of $8 \mathrm{~L} \mathrm{day}^{-1}$ ) which indicated that although the understorey used less water, it still made a significant contribution to the water balance given the abundance of understorey species in the indigenous forest.

The indigenous $C$. africana trees displayed a high water use during the summer period. As this is a deciduous tree, no water was used during leaf fall in winter. The largest $C$. africana tree had a canopy area of $75 \mathrm{~m}^{2}$ and was the largest tree at the site. Approximately $37700 \mathrm{~L}$ of water were transpired by this tree annually during the measurement period 
Table 2. Sap flow (daily and accumulated) for each species measured at Buffeljags River (January 2012 to March 2015).

\begin{tabular}{|c|c|c|c|c|c|}
\hline $\begin{array}{l}\text { Forest type/ } \\
\text { location }\end{array}$ & Species & $\begin{array}{r}\text { Diameter } \\
(\mathrm{mm})\end{array}$ & $\begin{array}{r}\text { Daily average } \\
\text { summer sap } \\
\text { flow }\left(\mathrm{L} \mathrm{day}^{-1}\right)\end{array}$ & $\begin{array}{r}\text { Daily average } \\
\text { winter sap } \\
\text { flow }\left(\mathrm{Lday}^{-1}\right)\end{array}$ & $\begin{array}{r}\text { Annual } \\
\text { accumulated } \\
\text { sap flow }\left(\mathrm{L} \mathrm{a}^{-1}\right)\end{array}$ \\
\hline \multirow{3}{*}{$\begin{array}{l}\text { Indigenous forest } \\
\text { site (upper reach) }\end{array}$} & V. lanceolata & 134 & 19 & 7 & 6534 \\
\hline & V. lanceolata & 199 & 37 & 6 & 15565 \\
\hline & Rothmania capensis & 125 & 11 & 4 & 4133 \\
\hline \multirow{3}{*}{$\begin{array}{l}\text { Introduced/alien forest } \\
\text { site (lower reach) }\end{array}$} & Acacia mearnsii & 194 & 25 & 8 & 9226 \\
\hline & Acacia mearnsii & 121 & 39 & 10 & 5469 \\
\hline & Acacia mearnsii & 167 & 32 & 9 & 7207 \\
\hline \multirow{3}{*}{$\begin{array}{l}\text { Indigenous cluster } \\
\text { (lower reach) }\end{array}$} & V. lanceolata & 174 & 14 & 6 & 5725 \\
\hline & V. lanceolata & 166 & 24 & 8 & 3430 \\
\hline & V. lanceolata & 202 & 39 & 14 & 9174 \\
\hline \multirow{2}{*}{$\begin{array}{l}\text { Indigenous cluster } \\
\text { (lower reach) }\end{array}$} & C. africana & 319 & 46 & 0 & 19821 \\
\hline & C. africana & 422 & 95 & 0 & 37769 \\
\hline
\end{tabular}

(Table 2). Given that this species is deciduous, it is important to note that this tree uses a high volume of water in summer when water resources are usually limited.

The indigenous cluster in the alien site had a LAI of 3.4, which was higher than the LAI of 3.1 under the nearby $A$. mearnsii trees. The indigenous trees in the upper-reach indigenous site had an LAI of 3.6. Although the summer water use was higher in the introduced trees, the radial sapwood area was larger in the indigenous trees (up to $413 \mathrm{~cm}^{2}$ ) than the introduced trees (up to $171 \mathrm{~cm}^{2}$ ). Trees with the highest sap velocities are therefore not necessarily those with highest whole-tree water use. However, this does indicate that the alien trees are more effective users of water, relative to their sapwood area.

\subsection{Soil profile and water content}

The volumetric soil water content (VWC) in the alien stand at Buffeljags River was very low, dropping to $7 \%$ during dry periods (Fig. 6). During high rainfall events, the soil VWC exceeded $20 \%$, showing a rapid but short response to rainfall. This indicates that the soil water moves through the soil profile rapidly with very little water being stored in the profiles, particularly in the lower profile. The soils had a dry bulk density $(\rho b)$ of $1.58 \mathrm{~g} \mathrm{~cm}^{-3}$, a particle density $\left(\rho_{\text {particle }}\right)$ of $2.66 \mathrm{~g} \mathrm{~cm}^{-3}$ and a porosity 0.42 , typically characteristic of sandy soils. The drying curve, after an isolated event, took on average $22 \mathrm{~h}$ from saturation to the expected field capacity (Fig. 6). A. mearnsii stands are known to have deep rooting systems, with observations of greater than $8 \mathrm{~m}$ in South Africa (Everson et al., 2007). This suggests that, during dry periods, this stand can access water from deeper layers in the soil profile.

In the indigenous stand (Fig. 7), the middle TDR probe $(0.3 \mathrm{~m})$ showed the highest water content. During the warmest period (December to April), there was very little water in the profile (even after rainfall events). This would suggest that the deeper roots from the indigenous species were readily using water below the TDR probe measurement depths as there was no correlation between transpiration and change in VWC. In contrast, the alien stand upper soil profile water content responded to rainfall events, indicating that interception storage (including throughfall and stemflow that contribute to litter catch) played a significant role when comparing these stands. After an isolated rainfall event, the drying period of the soil profile at the indigenous site took much longer (up to 1 week) from its peak to the driest level. The average soil water content at the indigenous stand was $5 \%$, lower than that of the alien stand, suggesting a difference in root activity given the same soil characteristics.

The VWC at both sites did not respond significantly to rainfall events under $5 \mathrm{~mm} \mathrm{~h}^{-1}$ except during consecutive events. The average water table depth, measured using an observation borehole, ranged from $5.2 \mathrm{~m}$ below the ground surface during the dry season to $3.2 \mathrm{~m}$ below the ground surface during the wet season (excluding extreme events). The water table recharge time showed a strong relationship to the soil wetting and drying response time recorded at both sites. In conclusion, both the indigenous and introduced stands are limited by atmospheric energy fluxes rather than water limitations as both stands had root contact with the water table.

\subsection{Upscaling tree water use}

The results obtained from the research area were used to determine an actual annual water use per unit area for both the invaded alien and pristine indigenous tree stands (Fig. 8). Using the stem density per size class, stands of forest were compared rather than individual trees. LAI and canopy area measurements undertaken indicated a closed canopy. The upscaled water use for a 3 -year average of the A. mearnsii stand was $5879 \mathrm{~L} \mathrm{ha}^{-1}$ for the small size class, $7639 \mathrm{~L} \mathrm{ha}^{-1}$ for the 


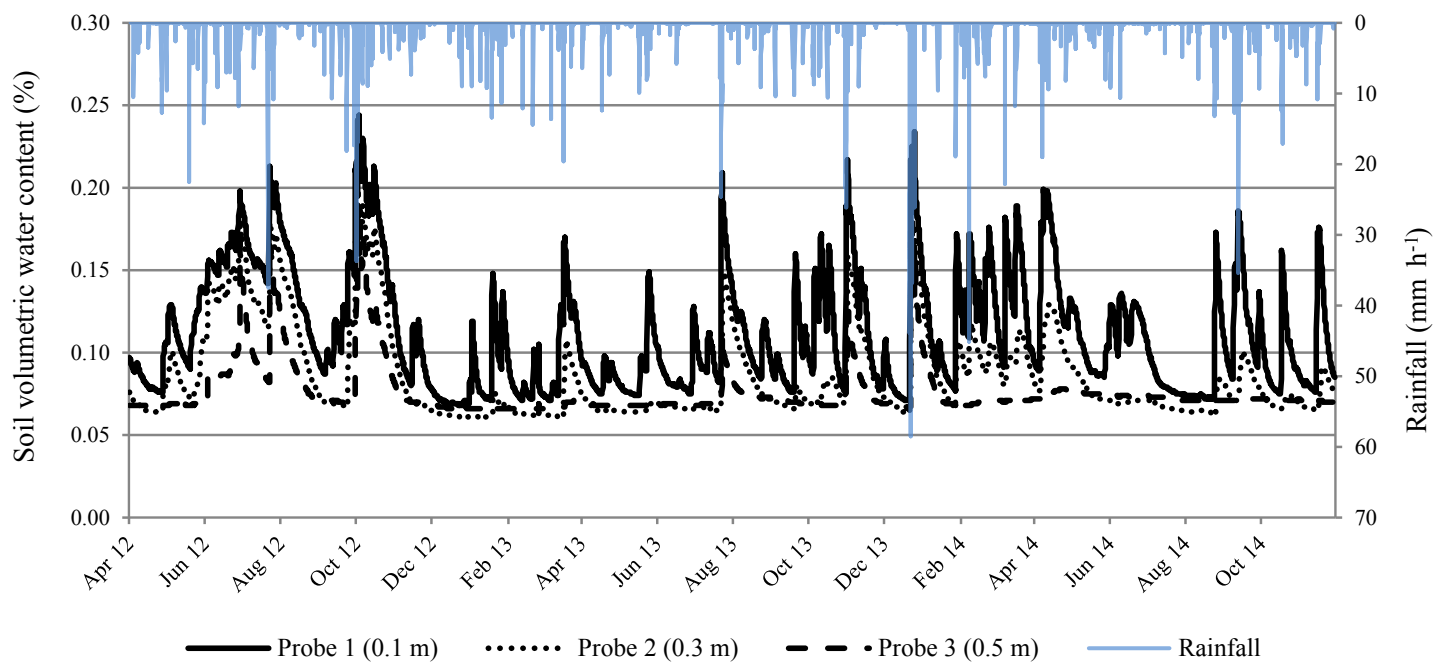

Figure 6. Hourly soil volumetric water content of the lower alien stand and the hourly rainfall at Buffeljags River from April 2012 to October 2014.

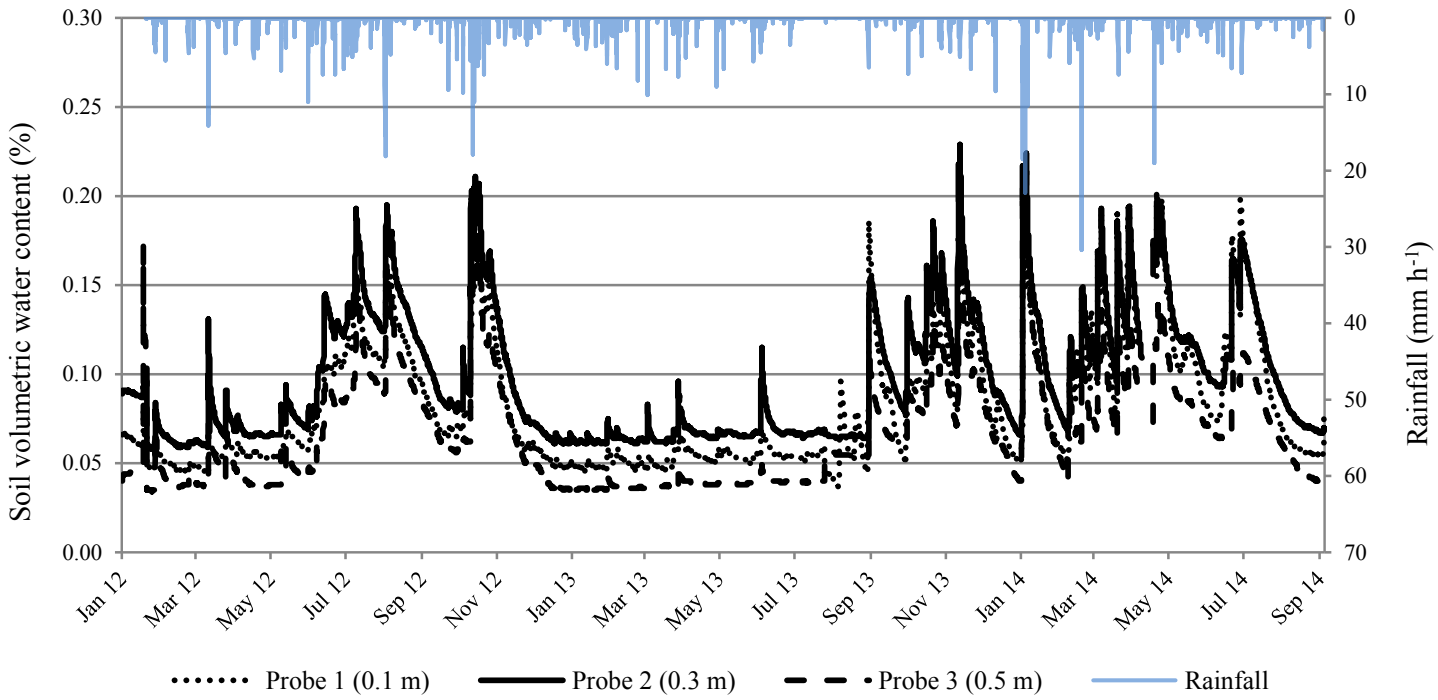

Figure 7. Hourly soil volumetric water content of the upper indigenous stand and the hourly rainfall at Buffeljags River from January 2012 to September 2014.

medium size class and $9981 \mathrm{~L} \mathrm{ha}^{-1}$ for the large size class. When upscaled for all species and size classes for the 3year average, the total stand water use was approximately $5.85 \mathrm{ML} \mathrm{ha}^{-1} \mathrm{a}^{-1}\left(585 \mathrm{~mm} \mathrm{a}^{-1}\right)$. This was $57 \%$ of the average annual precipitation recorded during the monitoring pe$\operatorname{riod}\left(1021 \mathrm{~mm} \mathrm{a}^{-1}\right)$.

The annual water use of the indigenous stand was $1209 \mathrm{~L} \mathrm{ha}^{-1}$ for the small size class, $6321 \mathrm{~L} \mathrm{ha}^{-1}$ for the medium size class and $18900 \mathrm{~L} \mathrm{ha}^{-1}$ for the large size class. The upscaled indigenous stand used $1.01 \mathrm{ML} \mathrm{ha}^{-1} \mathrm{a}^{-1}$ $\left(101 \mathrm{~mm} \mathrm{a}^{-1}\right)$. This was $9.8 \%$ of the average annual precipitation. Based on these results we concluded that the alien stand uses nearly 6 times more water per unit area annually than the indigenous stand. This roughly correlated to the growth rate of each stand, where the stem breast height diameter increase over the study period (recorded on each tree measured) was 3-8 times faster than similar-sized indigenous trees.

The inter-species and size class water-use variations, particularly within the indigenous stand, highlight the importance of good replications of a representative sample tree species and size classes. These results also highlight that individual indigenous trees, such as the $C$. africana, can use more water than an individual alien A. mearnsii tree. An example of this is the largest $C$. africana using $14000 \mathrm{~L}$ more water annually than the largest $A$. mearnsii. However, the $C$. africana tree had a much larger diameter and had a large canopy area under which no other trees grew, whereas ap- 


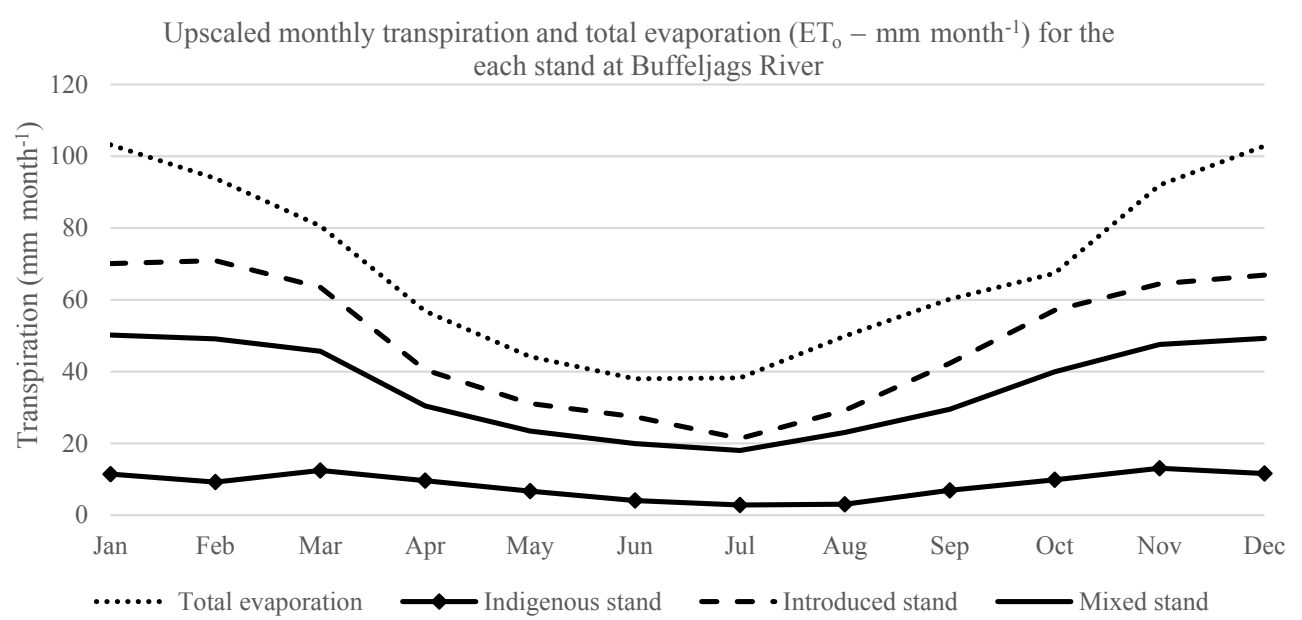

Figure 8. Upscaled monthly transpiration for the indigenous, introduced (A. mearnsii) and mixed stands in comparison to reference total evaporation.

proximately 10 medium-sized $A$. mearnsii trees could occupy the same area as this particular tree. The importance of upscaling using representative samples of species and size classes is clearly demonstrated by the study.

\section{Discussion and conclusion}

There is a widespread belief in South Africa that indigenous tree species, in contrast to introduced tree species, use less water and should be planted more widely in land rehabilitation programs (Olbrich et al., 1996; Dye, 2001; Dye et al., 2008; Everson et al., 2007; Gush and Dye, 2008, 2009; Gush et al., 2015). A review of relevant literature revealed a general paucity of information relevant to both indigenous and introduced tree water use, the methods of replication and the techniques used. Internationally, improved HPV techniques have been used with various vegetation types, and the accuracy of these studies has been validated using gravimetric methods (Granier et al., 2001; Burgess et al., 2001; O'Grady et al., 2006; Steppe et al., 2010; Vandegehuchte and Steppe, 2013). International studies indicate that, at the plant scale, introduced invasive species can use from $100 \%$ less water to between 150 and $300 \%$ more water than indigenous landscapes. Furthermore, there can be a significant disconnect between upscaling plant-scale measurements to an ecosystem scale (Cavaleri and Sack, 2010). In South Africa, the HPV technique has been shown to provide accurate estimates of sap flow in both introduced tree species such as A. mearnsii and Eucalyptus grandis, and indigenous tree species such as Podocarpus henkelii and C. africana (Smith and Allen, 1996; Dye, 2001; Dye et al., 2008; Everson et al., 2007). A key recommendation from the literature, which has been emphasized in a recent study by Gush et al. (2015), is that more indigenous tree stand management research is needed in South Africa.
Spatial estimates of evaporation and transpiration are required but are difficult to obtain in remote areas with limited aerodynamic fetch. A large capital and human effort was invested towards this study in order to extend the monitoring period, with a range of species and replicates. This allowed for an accurate comparison of indigenous and introduced tree water use. The Buffeljags River site is unique in that it is one of very few sites within South Africa with an extensive rehabilitation program that aims to assist WfW and similar clearing programs. The results showed that individual tree water use varies depending on size and species. Upscaled comparisons showed that stem density is important to the accurate representation of stand water use. A stand of introduced $A$. mearnsii can use up to 6 times more water annually than a mixed indigenous stand. This finding is significant in that it provides clear evidence to justify the highly expensive clearing programs, which have in the past lacked quantifiable data on the potential hydrological benefits of alien plant clearing. The results also indicate that rehabilitation or clearing programs need to consider the seasonal rainfall variability of a site, as planting of deciduous indigenous trees may provide larger benefits in summer rainfall areas due to no transpiration during periods when water resources are limited.

This study provides an ideal opportunity to validate remotely sensed ET data which could also be used to identify spatial variations in vegetation water use. This future research will allow for the broader extrapolation of alien plant water use and benefits of clearing riparian zones to similar areas outside of the immediate study area. Results may be used to further validate transpiration simulations from hydrological models, particularly in riparian areas.

Data availability. Due to the high-frequency data used for this paper, all data with linked figures and tables have been uploaded to the central database at the Centre for Water Resources Research 
(CWRR) at the University of KwaZulu-Natal in Pietermaritzburg. The author, Bruce Scott-Shaw, can be contacted for these data at brucecharlesss@gmail.com.

Competing interests. The authors declare that they have no conflict of interest.

Acknowledgements. The research presented in this paper forms part of an unsolicited research project (Rehabilitation of alieninvaded riparian zones and catchments using indigenous trees: an assessment of indigenous tree water use) that was initiated by the Water Research Commission (WRC) of South Africa. The project was managed and funded by the WRC, with co-funding and support provided by the Department of Economic Development, Tourism and Environmental Affairs (EDTEA). The land owners, Brian and Janet Kilpen of Frog Mountain Inn, are acknowledged for allowing field work to be conducted on their property. Assistance in the field by Terry Everson, Matthew Becker and Liandra Scott-Shaw is much appreciated.

Edited by: Dominic Mazvimavi

Reviewed by: two anonymous referees

\section{References}

Askey-Dorin, M., Petit, N., Robins, L., and McDonald, D.: The role of vegetation in riparian management, in: Riparian Land Management Technical Guidelines. Vol. 1. Principles of Sound Management, edited by: Lovett, S. and Price, P., LWRRDC Canberra, Australia, 97-120, 1999.

Atsame-Edda, A.: Regeneration dynamics of natural forest species within a stand of the invasive alien Acacia mearnsii along the Buffeljagsrivier, Swellendam, South Africa, MSc Thesis, Stellenbosch University, South Africa, 2014.

Baruch, Z. and Fernandez, D. S.: Water relations of native and introduced C4 grasses in a neotropical savanna, Oecologia, 96, 179$185,1993$.

Burgess, S. O., Adams, M. A., Turner, N. C., Beverly, C. R, Ong, C. K., Khan, A. A. H., and Bleby, T. M.: An improved heat pulse method to measure low and reverse rates of sap flow in woody plants, Tree Physiol., 21, 589-598, 2001.

Cavaleri, M. A. and Sack, L.: Comparative water use of native and invasive plants at multiple scales: a global meta-analysis, Ecology, 91, 2705-2715, 2010.

Cleverly, J. R., Smith, S. D., Sala, A., and Devitt, D.A.: Invasive capacity of Tamarix ramosissima in a Mojave Desert floodplain: the role of drought, Oecologia, 111, 12-18, 1997.

Clulow, A. D., Everson, C. S., Price, J. S., Jewitt, G. P. W., and Scott-Shaw, B. C.: Water-use dynamics of a peat swamp forest and a dune forest in Maputaland, South Africa, Hydrol. Earth Syst. Sci., 17, 2053-2067, https://doi.org/10.5194/hess-17-20532013, 2013.

Cullis, J., Görgens, A., and Marais, C.: A strategic study of the impact of invasive alien vegetation in the mountain catchment areas and riparian zones of South Africa on total surface water yield, Water SA, 33, 35-42, 2007
Dixon, P., Hilton, M., and Bannister, P.: Desmoschoenus spiralis displacement by Ammophila arenaria: the role of drought, New Zeal. J. Ecol., 28, 207-213, 2004.

Dye, P. J.: Modelling growth and water-use in four Pinus patula stands with the 3-PG process-based model, Southern African Forestry Journal, 191, 53-63, 2001.

Dye, P. J., Gush, M. B., Everson, C. S., Jarmain, C., Clulow, A., Mengistu, M., Geldenhuys, C. J., Wise, R., Scholes, R. J., Archibald, S., and Savage, M. J.: Water-use in relation to biomass of indigenous tree species in woodland, forest and/or plantation conditions, Water Research Commission Report No. 361/08, Water Research Commision, Pretoria, South Africa, 156 pp., 2008.

Everson, C. S., Gush, M. B., Moodley, M., Jarmain, C., Govender, M., and Dye, P.: Effective management of the riparian zone vegetation to significantly reduce the cost of catchment management and enable greater productivity of land resources, Water Research Commission Report No. 1284/1/07, Pretoria, South Africa, 92 pp., 2007.

Ford, C. R., McGuire, M. A., Mitchell, R. J., and Teskey, R. O.: Assessing variation in the radial profile of sap flux density in Pinus species and its effect on daily water-use, Tree Physiol., 24, 241-249, 2004.

Fritzsche, F., Abate, A., Fetene, M., Beck, E., Weise, S., and Guggenberger, G.: Soil-plant hydrology of indigenous and exotic trees in an Ethiopian montane forest, Tree Physiol., 26, 10431054, 2006.

Geldenhuys, C. J.: National forest types of South Africa: SA Forestry Magazine, Department of Agriculture, Forestry and Fisheries, Pretoria, South Africa, 2010.

Granier, A., Loustau, D., and Bréda, N.: A Generic Model of Forest Canopy Conductance Dependent on Climate, Soil Water Availability and Leaf Area Index, Ann. Forest Sci., 57, 755-765, 2001.

Gush, M. B.: Water-use, growth and water-use efficiency of indigenous tree species in a range of forest and woodland systems in South Africa, PhD dissertation, Department of Botany, University of Cape Town, Cape Town, South Africa, 2011.

Gush, M. B. and Dye, P. J.: Water-use Measurements of Selected Woodland Tree Species within the Kruger National Park. CSIR, Agrometeorology, School of Environmental Sciences, University of KwaZulu-Natal, Scottsville, South Africa, 2008.

Gush, M. B. and Dye, P. J.: Water-Use Efficiency Within a Selection of Indigenous and Exotic Tree Species in South Africa as Determined Using Sap Flow and Biomass Measurements. CSIR, Agrometeorology, School of Environmental Sciences, University of KwaZulu-Natal, Scottsville, South Africa, 2009.

Gush, M. B., de Lange, W. J., Dye, P. J., and Geldenhuys, C. J.: Water-use and Socio-Economic Benefit of the Biomass of Indigenous Trees, Volume 1: Research Report, Water Research Commission, Pretoria, South Africa, 2015.

Jarmain, C., Everson, C. S., Savage, M. J., Clulow, A. D., Walker, S., and Gush, M. B.: Refining tools for evaporation monitoring in support of water resource management. Water Research Commission Report No. 1567/1/08. Water Research Commision, Pretoria, RSA, 2008.

Jewitt, G.: Integrating blue and green water flows for water resources management and planning, Phys. Chem. Earth, 31, 753$762,2006$. 
Joshi, C., de Leeuw, J., and van Duren, I.C.: Remote sensing and GIS applications for mapping and spatial modelling of invasive species, ISPRS, Istanbul, Turkey, 669-677, 2004.

Kagawa, A., Sack, L., Duarte, K., and James, S. A.: Hawaiian native forest conserves water relative to timber plantation: Species and stand traits influence water-use, Ecol. Appl., 19, 1429-1443, 2009.

Le Maitre, D. C., van Wilgen, B. W., Chapman, R. A., and McKelly, D. H.: Invasive plants and water resources in the Western Cape Province, South Africa: modelling the consequences of a lack of management, J. Appl. Ecol., 33, 161-172, 1996.

Marshall, D. C.: Measurement of sap flow in conifers by heat transport, Plant Physiol., 33, 385-396, 1958.

Miller, G. R., Xingyuan, C., Yoram, R., and Baldocchi, D. D.: A new technique for upscaling sap flow transpiration measurements to stand or land use scale fluxes, Civil and Environmental Engineering, University of California - Berkeley, USA, 2007.

Mucina, L. and Rutherford, M. C.: The vegetation of South Africa, Lesotho and Swaziland. Strelitzia 19. South African National Biodiversity Institute, Pretoria, South Africa, 2011.

Nagler, P. L., Glenn, E. P., and Thompson, T. L.: Comparison of transpiration rates among saltcedar, cottonwood and willow trees by sap flow and canopy temperature methods, Agr. Forest Meteorol., 116, 73-89, 2003.

Nosetto, M. D., Jobbagy, E. G., and Paruelo, J. M.: Landuse change and water losses: the case of grassland afforestation across a soil textural gradient in central Argentina, Glob. Change Biol., 11,1101-1117, 2005.

O'Grady, A. P., Cook, P. G., Howe, P., and Werren, G.: An assessment of groundwater-use by dominant tree species in remnant vegetation communities, Pioneer Valley, Queensland, Aust. J. Bot., 54, 145-154, 2006.

Olbrich, B., Olbrich, K., Dye, P. J., and Soko, S. A.: YearLong Comparison of Water-use Efficiency of Stressed and NonStressed E. grandis and P. patula: Findings and Management Recommendations, CSIR report FOR-DEA 958. CSIR, Pretoria, South Africa, 1996.

Pratt, R. B. and Black, R. A.: Do invasive trees have a hydraulic advantage over native trees?, Biol. Invasions, 8, 1331-1341, 2006.

Reid, A. M. L., Morin, P. O., Downey, K., French, K. O., and Virtue, J. G.: Does invasive plant management aid the restoration of natural ecosystems?, Biol. Conserv., 142, 2342-2349, 2009.

Richardson, D. M., Rouget, M., Ralston, S. J., Cowling, R. M., Van Rensburg, B. J., and Thuiller, W.: Species richness of alien plants in South Africa: Environmental correlates and the relationship with indigenous plant species richness, Ecoscience, 12, 391-402, 2005.
Savage M. J., Everson, C. S., Odhiambo, G. O., Mengistu, M. G., and Jarmain, C.: Theory and practice of evaporation measurement, with a special focus on SLS as an operational tool for the estimation of spatially-averaged evaporation, Water Research Commission Report No. 1335/1/04. Water Research Commission, Pretoria, RSA, 2004.

Scott, D. F.: Managing riparian zone vegetation to sustain streamflow: Results of paired catchment experiments in South Africa, Can. J. Forest Res., 29, 1149-1157, 1999.

Scott, D. F. and Lesch, W.: The effects of riparian clearing and clearfelling of an indigenous forest on streamflow, stormflow and water quality, S. Afr. For. J., 175, 1-14, 1996.

Smith, D. and Allen, S.: Measurement of sap flow in plant stems, J. Exp. Bot., 47, 1833, https://doi.org/10.1093/jxb/47.12.1833, 1996.

Solarz, W.: Biological invasions as a threat for nature, Prog. Plant Prot., 47, 128-133, 2007.

Steppe, K., De Pauw, D. J. W., Doody, T. M., and Teskey, R. O.: A comparison of sap flux density using thermal dissipation, heat pulse velocity and heat field deformation methods. Laboratory of Plant Ecology, Department of Applied Ecology and Environmental Biology, Faculty of Bioscience Engineering, Ghent University, Gent, Belgium, 2010.

Swanson, R. H. and Whitfield, D. W. A.: A Numerical Analysis of Heat Pulse Velocity Theory and Practice, J. Exp. Bot., 32, 221239, 1981.

Tabacchi, E., Lambs, L., Guilloy, G., Planty-Tabacchi, A. M., Muller, E., and de'Camps, H.: Impacts of riparian vegetation on hydrological processes, Hydrol. Process., 14, 2959-2976, 2000.

Turpie, J. K., Marais, C., and Blignaut, J. N.: The working for water programme: Evolution of a payments for ecosystem services mechanism that addresses both poverty and ecosystem service delivery in South Africa, Ecol. Econ., 65, 788-798, 2008.

Vandegehuchte, M. W. and Steppe, K.: Sap-flux density measurement methods: working principles and applicability, Laboratory of Plant Ecology, Faculty of Bioscience Engineering, Ghent University, Gent, Belgium, 2013.

Wal, R. V. D., Truscott, A. M., Pearce, I. S. K., Cole, L., Harris, M. P., and Wanless, S.: Multiple anthropogenic changes cause biodiversity loss through plant invasion, Glob. Change Biol., 14, 1428-1436, 2008.

Yepez, E. A., Huxman, T. E., Ignace, D. D., English, N. B., Weltzin, J. F., Castellanos, A. E., and Williams, D. G.: Dynamics of transpiration and evaporation following a moisture pulse in semiarid grassland: a chamber-based isotope method for partitioning flux components, Agr. Forest Meteorol., 132, 359-376, 2005. 